\title{
FINANCIAL DECENTRALIZATION AS A FUNDAMENTAL CONDITION FOR INDEPENDENCE OF LOCAL AUTHORITIES
}

\author{
Latkovskyi P. P.
}

\section{INTRODUCTION}

The issues of decentralization are relevant from the standpoint of different legal sciences, particularly financial and legal. The democratic transformations taking place in Ukraine, the activation of the processes of formation of civil society institutions and the building of a democratic, social and legal state require a combination of all directions of modernization of contemporary Ukrainian society and an effective improvement of the mechanism of state power, which in turn requires adequate financial support.

When the state became independent, the processes aimed at the formation and development of local self-government, according to the European model, became more active, moving away from subordination of local authorities to state authorities, as it used to be during Soviet times.

Over the years of independence, the concept of local authorities has changed several times. Back in December of 1990 (later in the version of March 26, 1992), the Law "On Local Councils of People's Deputies, Local and Regional Self-Government" was adopted, according to which the councils were limited to the functions of local and regional self-government. Meanwhile the executive functions were transferred to the representatives of the President of Ukraine in the regions and districts, as well as in the cities of Kyiv and Sevastopol. The reform of local government was suspended since February 1994, when the Verkhovna Rada adopted the Law "On the Formation of Local Authorities and Self-Governance" and returned power to local councils and their executive committees. After the adoption of the Constitution of Ukraine, the executive power in the regions and districts of Kyiv and Sevastopol was transferred to local State Administrations, that became accountable to and controlled by the executive bodies of a higher level. The powers of local State Administrations are defined by the Constitution of Ukraine by Article 119 and the Law of Ukraine "On Local State Administrations", adopted on April 9, 1999 ${ }^{1}$. In accordance with this Law, heads of local State Administrations are appointed by the President of Ukraine on the submission of the Cabinet of Ministers of Ukraine for the term

1 Про місцеві державні адміністрації. Закон України від 9.04 .1999 р. Відомості Верховної Ради України. 1999 № 20-21. St. 190. 
of office of the President of Ukraine. Candidates for the positions of the heads of District State Administrations shall be nominated by the heads of the respective Regioanl State Administrations and submitted to the Cabinet of Ministers of Ukraine. The norms of the Law stipulate that the powers of the heads of local State Administrations may be terminated by the President of Ukraine in the following cases: the resignation of the head of the relevant Regioanl State Administration; submission of the Prime Minister of Ukraine; impeached credibility by a majority of votes from the members of the relevant council; on the initiative of the President of Ukraine.

The Constitution of Ukraine contains a separate section devoted to local self-government. However, the constitutional norms have been further developed in the Law of Ukraine "On Local Self-Government", adopted on May $21,1997^{2}$. Where the territorial community of villages, settlements, cities is defined as the basis of local self-governance, both directly and indirectly, through villages, settlements, city councils and their executive bodies. As well as through district and region councils representing the common interests of territorial communities of villages, settlements and cities.

The development of Ukraine as an independent state with European values requires improving the quality of public administration in various areas of state policy, the formation of effective local self-government based on decentralization of power and the availability of appropriate financial support. Market transformations that take place in Ukraine require new approaches to formulating the state policy of regional development and reforming of local self-government. The vector of reforms in Ukraine in this direction has been the processes of financial decentralization as the most effective form of public finance management, which fully corresponds to a new system of social relations, built on market principles, as well as processes of democratization of all areas of society's life. Financial decentralization is one of the fundamental conditions for the independence and viability of local authorities. Yet decentralization of decision-making processes increases the opportunities for local authorities to participate in the development of their own territory. It also promotes effective provision of public services through a close matching of expenditures of local authorities with top priority needs.

\section{Local Public Authority: New Challenges in the Financial Decentralization}

Today, the decentralization of public authority in Ukraine is stipulated by the necessity of transition to a modern European model of public administration, refusal of centralized administration, new paradigm of

${ }^{2}$ Про місцеве самоврядування. Закон України від 9.04.1999 р. Відомості Верховної Ради України. 1997 №. 24. Art. 170 
governance in the country, organizations at the territorial level of state power and local self-government with the essential financial support for the relevant transformations.

Generally, the issue of changing relations between power and subordination has been attracting the attention of scientists and practitioners for a long time. After all, humanity has not yet come up with a better way other than to manage a country with the help of money. In addition, where there is power, there are also public funds, and it is the bodies of public authority, which are involved in drafting, reviewing, approving, executing the budgets, reporting on their implementation, monitoring compliance with budget laws and issues connected with responsibility for violations of both tax and budgetary laws. Therefore, when relevant changes within the authorities emerged, there was a need to change the approaches to the formation, distribution and use of public funds.

An important step towards the formation and development of a rule-of-law state and civil society is the formation and development of local public authorities. The purpose of state policy in the field of decentralization is to move away from the centralized model of governance, to ensure the financial capacity of local public authorities and to build an effective system of territorial organization of authorities in Ukraine. The current stage of Ukraine's development, the ongoing constitutional reform, integration with the European Union requires a new understanding and meaning of the role of local public authorities, especially when it comes to the issue of financial decentralization.

Local public authorities, depending on their functional purpose, have two components: the power of local bodies of state executive power and authorities of local self-government bodies. The basis of the first one is about the necessity to ensure the fulfilment of the state functions on a certain territory, and the basis of the second one is about the necessity of the local community to manage local affairs.

A significant step in the development of local self-government was the adoption of the Constitution of Ukraine on June 28, 1996. Art. 140 states that: "Local self-government is the right of a territorial community - residents of a village or a voluntary amalgamation into a village community of residents of several villages, settlements and cities - to independently resolve local issues within the Constitution and laws of Ukraine" ". Article 143 of the Constitution stipulates that the territorial communities of villages, settlements, cities, directly or through the local self-government bodies, manage the property of

3 Конституція України від 28.06.1996 № 254к/96-ВР. Відомості Верховної Ради України. 1996. № 30. ст. 141 
the communal ownership; approve socio-economic and cultural development programs and control their implementation; approve budgets of the relevant administrative and territorial units and control their implementation; establish local taxes and fees in accordance with the law; ensure the holding of local referendums and the implementation of their results; form, reorganize and liquidate communal enterprises, organizations and institutions, as well as control their activities; solve other issues of local importance, which by law are assigned to their competences.

In 1997, the Law of Ukraine "On Local Self-Government in Ukraine" was adopted, after the introduction of which, the problems of lack of autonomy for local self-government bodies and the necessity of decentralization became increasingly frequent ${ }^{4}$.

The law establishes a norm according to which "local self-government in Ukraine is considered to be a right guaranteed by the state and the ability of the territorial community, particularly the inhabitants of the village or the voluntary amalgamation of the villagers of several villages, settlements, cities - independently or under the responsibility of local authorities and officials of self-government bodies to resolve issues of local importance within the Constitution and laws of Ukraine". The territorial community, in accordance with the law, is inhabited by permanent residents within a village, a settlement, a city that is an autonomous administrative and territorial unit, or a voluntary consolidation of residents of several villages having a single administrative centre.

The system of local self-government according to Art. 5 of the Law of Ukraine "On Local Self-Government" includes:

- territorial community;

- village, settlement, city councils;

- village, settlement, city heads;

- executive bodies of village, settlement, city councils;

- a village elder (starosta);

- district and regional councils representing the common interests of territorial communities of villages, settlements, cities;

- bodies of self-organization of the citizens.

The state policy of Ukraine in the field of local self-government is based on the interests of the citizens of territorial communities and envisages the decentralization of power. That is, the transfer of a significant part of powers, resources and responsibilities from the bodies of executive power to the bodies of local self-government. The basis for this policy is the provisions of

\footnotetext{
${ }^{4}$ Про місцеве самоврядування : Закон України від 9.04.1999 р. № 280/97-ВР. Відомості Верховної Ради Украӥни. 1997. № 24. Ст. 170.
} 
the European Charter of Local Self-Government and the best world standards of social relations in this area.

The legal basis for a radical change in the system of government and its territorial basis at all levels began to emerge in 2014.

So, on April 1, 2014, a local self-government reform was launched, based on the provisions of the European Charter of Local Self-Government. It is implemented on the basis of the Concept of Reform of Local SelfGovernment and Territorial Organization of Power. After that, an Action Plan regarding its implementation was approved, which gave rise to the reform.

In order to implement the provisions of the Concept and the objectives of the Action Plan, it was necessary, first of all, to make appropriate amendments to the Constitution of Ukraine, as well as to formulate a package of new legislation.

Changes to the Constitution first of all had to solve the issue of creating executive bodies of regional and district councils, reorganization of local state administrations into the bodies of control and supervision, and give a clear definition of the administrative-territorial unit, which is a community.

With the efforts of Ukrainian practitioners and scholars, the draft amendments to the Constitution were made and proposed to a broad public discussion. These changes were supported by the community and highly appreciated by the Venice Commission.

Unfortunately, however, political circumstances did not allow the Verkhovna Rada of Ukraine to accept the changes of the Constitution, regarding the decentralization, submitted by the President of Ukraine.

Therefore, the Government launched the reform in 2014 within the framework of the current Constitution.

During this time, the basic package of new legislation has already been formed and is in operation, and top-priority legislative initiatives are being implemented. This applies to the Laws on Amendments to the Budget and Tax Codes of Ukraine. Due to these changes, financial decentralization took place: local budgets have grown by 123.4 billion UAH in recent years: from 68.6 billion in 2014 to 192 billion UAH in $2017^{5}$. The Law "On Voluntary Amalgamation of Territorial Communities" enabled the formation of a capable basic local self-government. By the beginning of September 2018, 838 amalgamated territorial communities have already been formed. Among them 133 ATCs are waiting for the appointment of the first elections, and 3839 former local councils have been included in these $\mathrm{ATCs}^{6}$. International experts

${ }^{5}$ Приходько В.П., Єгорова О.О. Децентралізація в Україні: https://dspace.uzhnu.edu.ua/ jspui/bitstream/lib/19803/1/Децентралізація_для\%20сайту.pdf

${ }^{6}$ https://decentralization.gov.ua/about 
consider such pace of inter-municipal consolidation as very high. The law also introduced the Institute of Village Elders (starosta) in ATC, which represents the interests of rural residents in the community council. There are already 780 elders in the ATC villages, and almost 1.8 thousand people are acting elders. The Law of Ukraine "On Cooperation of Territorial Communities" has created a mechanism for solving common problems of communities: utilization and recycling of garbage, development of a common infrastructure, etc. So far, 263 cooperation agreements are already being implemented. This mechanism was used by 1050 communities. The Law of Ukraine "On the Principles of State Regional Policy" created the conditions for state support for regional development and community infrastructure development during the reform, which is confirmed by an increase of 39 times. A number of other Laws, such as: The Law of Ukraine "On Amendments to Certain Legislative Acts of Ukraine on Decentralization of Authorities in the Field of Architectural and Construction Control and Improvement of Urban Development Legislation" and the number Laws on the Empowerment of Local Self-Government Bodies and Optimization of the Administrative Services have also contributed to financial decentralization, which allowed to delegate the appropriate level of authority that provide basic administrative services to the bodies of local self-government. Among them: registration of residence, issuing of passport documents, state registration of legal entities and individuals, entrepreneurs, NGOs, marriage registration, proprietary interest, land issues etc.

The main task of the reform is to achieve an optimal division of powers between local governments and executive authorities at different levels of the administrative and territorial system on the principles of subsidiarity and decentralization. The first step towards implementation of the reform was the task regarding the financial decentralization, which began with the adoption of amendments to the Budget, Tax Codes and other legislative acts of Ukraine.

If we refer to the researches of European scholars, the relevant legal literature reveals the content of fiscal decentralization through the following three aspects:

- Decentralization of expenditures: providing local self-government with financial resources to fulfil tasks and functions;

- Decentralization of incomes: the consolidation of the list of revenues by the local self-government, sufficient for proper and qualitative fulfilment of the tasks and functions set for the relevant level of local self-government, and the right to independently establish their size;

- Procedural and organizational independence: the right to independently formulate, approve, execute financial plans, estimates, budgets, provide reporting and control under the responsibility of bodies and officials of local self-government bodies. 
In our opinion, this vision is not just about the understanding of decentralization but rather understanding of local government itself. If a totalitarian country, which does not have local self-government, starts the processes involving the development of the rights of territorial communities or other territorial entities, then in this case, we can speak of the decentralization of power. That means, the state transfers some of its functions to the local level.

If local government already exists, if budget legislation attaches relevant incomings (fixed, personal, regulating revenues) to budgets of different levels, if expression of will is conducted at local level (through elections, referendums), then this means that the government is already decentralized.

Then the following contradiction may arise: the state seeks to minimize the transfer of budget funds to local level (saying, there are personal and fixed revenues of local budgets, then let local governments create conditions for their growth, and inter-budget transfers should become an additional source of income). At the same time, the Cabinet of Ministers is very active in the creation amalgamated territorial communities and thus supports direct interbudget relations between the state and such communities.

It seems that someone is keen to give a part of the inter-budget transfers to local levels bypassing other bodies, budgets, etc.

The conclusion of some scholars may seem to be interesting that even after the amalgamation, the majority of territorial communities will hardly be able to become financially self-sufficient. The planned average size of the rural communities of Ukraine with 9 thousand citizens, even in such high-income countries as Finland, did not allow to perform a wide range of functions.

Experience of foreign countries shows that the optimal performance of health care functions is possible in a community of more than 20 thousand people, and educational functions in more than 50 thousand citizens. This means that even amalgamated territorial communities need additional tools for combining efforts with other communities to perform a number of functions.

It should be noted, that according to the legislation, the budget system of Ukraine consists of the State Budget and Local Budgets. Local budgets are the budget of the Autonomous Republic of Crimea, regional, district budgets and budgets of local self-government. If earlier, the budgets of local selfgovernment were considered as the budgets of territorial communities of villages, their associations, settlements, cities (including city districts) then in 2015 they were supplemented with a new component, that is the budgets of the amalgamated territorial communities ${ }^{7}$.

\footnotetext{
${ }^{7}$ Про внесення змін до Бюджетного кодексу України та деяких інших законодавчих актів України. Закон України від 10.02.2015 № 176-VIII. Відомості Верховної Ради України. 2015. № 16. ст. 107.
} 
In 2017, Art. 5 of the Budget Code was supplemented by paragraph 2 saying: the budgets of amalgamated territorial communities are considered to be the budgets of these communities established in accordance with the law and a prospective plan of the formation of community territories, as well as budgets of amalgamated territorial communities, recognized by the Cabinet of Ministers of Ukraine as effective budget, established by law ${ }^{8}$.

Effective organization of relations in the budget system is one of the most important and complicated tasks of public finance in each country. The main problems of the relationship between the state budget and the budgets of local self-government bodies are redistribution of budgetary resources, due to objective differences in the levels of social and economic development of separate territories and the need for financial equalization with the aim of providing constitutional guarantees to the population, regardless of the place of residence. Inter-budgetary relations are an important factor in equalizing the development of territorial communities, which ensures equal access of citizens to public services regardless of location.

Formation and implementation of local budgets depends essentially on solving their balancing issues, which is the result of unresolved issues regarding the ratio of fiscal centralization and decentralization. At the same time, problems of budgetary equalization derive from the disproportion and imbalance of the financial base of local self-government. It is budgetary decentralization, that anticipates the connection of the list of revenues to the local self-government bodies, which is sufficient for proper fulfilment of the established powers and functions, as well as the right to independently establish the norms of their incomings to the relevant local budgets.

Balancing local budgets of one level, which can not be carried out only by delimiting their revenues and expenditures, is achieved through the budget regulation, that is, redistributive processes within the budget system. Such redistribution is carried out between the State Budget and local budgets. In other words, fiscal regulation can be defined as an activity aimed at balancing budgets of all levels and types. Budget regulation is an extremely complicated and responsible activity within the budget system, it belongs to a special place in the inter-budgetary relations. In the process of budget regulation, many tasks are being solved, the most significant among them are:

- to achieve conformity between different types of expenditures and revenues of local budgets, that is, their balancing;

- to ensure equal incomes for preventing interruptions in the financing of expenditures;

${ }^{8}$ Про внесення змін до Бюджетного кодексу України. Закон України від 07.12.2017 № 2233-VIII. Відомості Верховної Ради України. 2018. № 2. ст. 8 
- to create interest for local self-government bodies in the full mobilization of incomes in their territory;

- to provide independence in the use of additional funds received in the process of implementation of local budgets;

- to implement financial equalization.

\section{Amalgamated Territorial Communities as a Component of the Budget System of Ukraine}

The Law of Ukraine "On Voluntary Amalgamation of Territorial Communities", adopted in 2015, allowed, in addition to existing ones, to create new amalgamated territorial communities with their own budgets, which funds are allocated directly from the State Budget of Ukraine ${ }^{9}$. The law regulates relations that arise in the process of voluntary amalgamation of territorial communities of villages, settlements, cities, as well as voluntary joining to the amalgamated territorial communities. According to Art. 10 of the Law, the state provides financial support for the voluntary amalgamation of territorial communities of villages, settlements, cities and joining to the already amalgamated territorial communities by providing the community with funds in the form of subventions for the formation of the appropriate infrastructure in accordance with the plan of socio-economic development of such territorial community. Proposals for providing financial support to the amalgamated territorial community shall be submitted by the relevant Regional State Administration upon submission of the the village, settlement, city councils of the amalgamated territorial community to the Cabinet of Ministers of Ukraine not later than July 15 of the year preceding the budget period, which prescribes such financial support.

The total amount of financial support in accordance with the law is distributed among the budgets of the amalgamated territorial communities in proportion to the size of the community and the number of rural residents in such territorial community with equal significance of both of these factors. Moreover, the total amount of subventions for the formation of the corresponding infrastructure of the amalgamated territorial communities is determined by the law on the State Budget of Ukraine, and the procedure for providing subventions from the State budget to amalgamated territorial communities is established by the Cabinet of Ministers of Ukraine.

However, as it has been confirmed by the experience of using inter-budget transfers since the adoption of the Budget Code, the procedure for providing the transfers did not create sufficient incentives to increase the revenues of

9 Про добровільне об'єднання територіальних громад : Закон України від 5 лютого 2015 року № 157-VIII. Відомості Верховної Ради Украӥни. 2015. № 13. Ст. 91. 
local self-government bodies, did not facilitate the search for additional reserves and attract alternative sources, but encouraged consumers' sentiments.

The reform of decentralization gave impetus, by increasing the number of territorial communities, to the formation of local self-government, as the most capable and the most citizen friendly institution of power. The voluntary amalgamation of territorial communities allowed the newly formed local selfgovernment bodies to obtain the corresponding powers and resources that previously belonged to the cities of regional significance.

The interests of citizens living in the territory of the amalgamated community are now represented by the elected head, deputy corps and executive bodies of the community council that ensure the exercise of the powers provided by law in the interests of the community. In the settlements that are part of the amalgamated community, the right of residents to local self-government and rendering of services to citizens is ensured by their elected elders.

The increase and amalgamation of communities is carried out by voluntary amalgamation, taking into account the opinion of citizens. It is obligatory, when planning community building, to determine potential community resources for economic and social development and the possibility to provide quality services to the residents.

The state stimulates the process of voluntary amalgamation by financial support for the formation of the necessary ATC infrastructure: in 2017, the subvention amounted to $1.5 \mathrm{UAH}$ billion, in 2018 it was $1.9 \mathrm{UAH}$ billion. Due to this financial support, 366 ATCs implemented 2046 projects in $2017^{10}$.

Services available to the citizens are ensured through the formation of a network of centres for administrative services, 723 of them are currently operating in Ukraine.

Thus, the new legislative framework has greatly enhanced the motivation for inter-municipal consolidation in the country, has created the right legal conditions and mechanisms for the formation of capable territorial communities of villages, settlements, cities, which unite their efforts in solving urgent problems. Also, a new model of financial support for local budgets, which received some autonomy and independence from the State Budget, has already justified itself.

The Cabinet of Ministers has determined support for the decentralization reform in Ukraine as one of the priority tasks that will contribute to the

10 Реформа децентралізації. Урядовий портал : https://www.kmu.gov.ua/ua/diyalnist/ reformi/reforma-decentralizaciyi 
development of local government and economic development of the country as a whole. The year of 2018 should become crucial for the formation of the basic level of local self-government: by the end of the year, most of the existing small local councils can unite, and thus become able to assume most of their powers, use resources properly and bear responsibility for their actions or inactivity in front the citizens and the state. This will create a solid foundation for the next steps in the reform of local self-governance and will also help accelerate health, education, social services, energy efficiency and other sectors. Whether all this succeeds, time will show.

Today, in order to improve the legislative framework, the following significant laws are going to be adopted: The Law "On Service in Local SelfGovernment Bodies" (new edition), which will ensure equal access to services in local self-government bodies, enhance the prestige of service in the local government authorities, motivation of local servants to develop community and personal effectiveness; the Law "On the Principles of the AdministrativeTerritorial System of Ukraine" (the bill is ready for consideration in the Verkhovna Rada). The latter defines, under the current Constitution, the principles of functioning of administrative-territorial structure of Ukraine, the types of settlements, the system of administrative-territorial units, the bodies of state power and bodies of local self-government regarding the issues of administrative and territorial organization, the procedure for the establishment, liquidation and changes of the boundaries of administrative territorial units and residential areas, operation of the State Register of Administrative Units and Settlements of Ukraine. Regarding the management of land resources within the territory of the amalgamated territorial communities, this bill should introduce the principle of the general jurisdiction of the ATC in terms of land relations and give power to use of the lands located beyond the settlements. The Law regarding state supervision over the legitimacy of decisions of local self-government bodies. Another law pending for approval is "On urban agglomerations", the norms of which will determine the organizational and legal basis for the formation of urban agglomerations by territorial communities of villages, settlements and cities, including the amalgamated territorial communities, the principles and mechanisms of interaction of territorial communities within urban agglomerations, as well as forms of support by the state.

Thus, the constitutional principles of local self-government have been established in Ukraine as well as the European Charter of Local SelfGovernment has been ratified and a number of basic legal acts have been adopted that create legal and financial bases for the activities of local self-government bodies. However, since the adoption of the Constitution of Ukraine and basic legal acts on local self-government, its development was 
actually implemented only at the level of territorial communities of the cities of regional significance. So far as the vast majority of territorial communities, due to their small territories and extremely weak material and financial resources, was incapable of performing all powers of local self-government bodies. The system of local self-government today does not meet the needs of society. The functioning of local self-government bodies in most of the territorial communities does not ensure the creation and maintenance of favourable living environment necessary for the full individual development, personal fulfilment, protection of human rights, high-quality, accessible administrative, social and other services in the respective territories ${ }^{11}$.

It is early to talk about successful reforms at the first stage, but it is clear that deferment is no longer possible. The next step that should be taken is to amend the Constitution regarding decentralization, which is necessary for the further implementation of the reform and its completion.

The peculiarities of forming budgets of the amalgamated territorial communities are as follows.

Firstly, ATCs budgets have inter-budget relations with the State Budget.

Inter-budget transfers are divided into:

1) basic subsidy (transfer from the state budget to local budgets for horizontal equalization of fiscal capacity of territories);

2) subventions (subventions - inter budget transfers for special purpose to be allocated in the order determined by the body responsible for the decision of granting a subvention). The Budget Code does not have a term subsidy (a subsidy is a financial aid provided by the state from the budget funds, as well as special funds for legal entities and local government bodies). This is a form of assistance for the targeted individuals, provided by using budget funds or trust funds. However, one of the principles of the budget system is the principle of subsidiarity, according to which the distribution of types of expenditures between the State Budget and local budgets, as well as among other local budgets, is based on the need for maximum realization of the provision of guaranteed services to their immediate consumers.

3) reverse subsidy (funds transferred to the State Budget from local budgets for horizontal equalization of the fiscal capacity of territories);

4) additional subsidies.

That is, the volume of inter-budget transfers is approved for the ATCs' budgets according to the Law on the State Budget for the plan year. This is a basic subsidy, an educational subvention, a medical subvention, other subventions and grants, if there are reasons for granting and receiving the

11 Концепція реформування місцевого самоврядування та територіальної організації влади в Україні : Розпорядження Кабінету Міністрів України від 1 квітня 2014 р. № 333-р. 
corresponding inter-budget transfers (Articles 97, 99, 100, 102, 103-2, 103-4 and 108 of the Budget Code $^{12}$ ).

It should be noted that the budgets of non-amalgamated communities do not receive inter-budget transfers from the State Budget.

Secondly, except for the budget incomes received before the ATCs' amalgamation, $60 \%$ of the personal income tax is credited to their budgets. Previously, this tax was credited to the district budget.

The list of revenue sources for ATC budgets is defined by Articles 64 (general fund), 69-1 (special fund) and 71 (budget development) of the Budget Code.

Thirdly. Except for expenditures of self-government powers, the ATCs budgets will finance expenditures that are delegated by the state, namely: expenditures for maintenance of institutions of the public sector - education, culture, health care, physical culture and sports, social protection and social provision (the list of expenditures is defined in Articles 71, 89 and 91 of the Budget Code).

The source of financing expenditures is both coming from the revenues secured for the ATCs budgets the by the Budget Code and inter-budget transfers from the State Budget (basic subsidy, educational and medical subventions, other subsidies and subventions).

Thus, ATCs budgets are involved in horizontal equalization of fiscal capacity.

This system of equalization suggests that basic subsidies ( 80 percent of the amount needed to achieve the indicator of 0.9) will be provided to local budgets with a level of taxable capacity (average income per inhabitant) below the 0.9 average for Ukraine in order to increase their level of security.

In case if the level of taxable capacity of the ATC budget ranges from 0.9 to 1.1 among the average indicators for Ukraine, then horizontal equalization of the taxable capacity is not carried out.

At the same time, ATC budgets (as well as other local budgets interrelating with the State budget), in which the level of taxable capacity is above the 1.1 national average indicator in Ukraine, the parts of the revenue are being transferred to the State Budget (reverse subsidy). At the same time, funds are not withdrawn in full extent, as it used to be with the system of balancing of local budgets, but only 50 percent of the excess of the taxable capacity index of 1.1 in relation to the average in Ukraine.

It should be noted that the reverse subsidy is a source of funding for the basic subsidy.

12 Бюджетний кодекс від 8 липня 2010 року № 2456-VI. Відомості Верховної Ради України. 2010. № 50-51. Т. 572. 
At the same time, as in other budgets (oblast, district and cities of oblast significance), equalization is carried out with only one tax, that is personal income tax. This issue is regulated by Art. 99 of the Budget Code. The rest of the payments remain in full possession of the local authorities.

Also, the ATCs' councils have the right to make local borrowings to their budgets, both local and inner ones, including loans from international financial organizations. Borrowings are made for the development budget and funds are directed to implementation of investment programs (projects) aimed at the development of communal infrastructure, the introduction of resource-saving technologies, creation, increase or renewal of strategic objects of long-term use or objects that ensure the implementation of the tasks of city councils, aimed at satisfying the interests of the population of their communities.

In addition to the specific features of the ATC budgets, there is a number of features for applying the provisions of other articles of the Code for the first planned budget period after the amalgamation. Such features are defined in paragraph 38 of the Final and Transitional Provisions of the Code.

\section{CONCLUSIONS}

Today, local self-government bodies, using financial decentralization tools, provide sustainable local economic development. First of all, financial decentralization encourages local self-government bodies to fill local budgets with their own fixed income. Such as: land payment, property tax, among legal entities, there is also the so-called fourth group paid by farmers who lease land. In addition, 5\% of alcohol sales, fuel, lubricants and tobacco are paid to local budgets. For this money, local government was able to implement infrastructure projects for the development of territories during the year.

At the same time, the fact of inefficient use of funds at the local level is observed. First of all, this is about the absence of development projects. This tendency means that local self-government bodies do not always understand the main goal of decentralization reform, which is to improve the quality of life in communities.

Taking into account the high risks of corruption while using budget funds, it is relevant to introduce mechanisms for monitoring the activities of local self-government bodies, both from state authorities and from the community residents.

In the conditions of budget decentralization there is a need for proper control over the work of the authorities of different levels in the process of planning and execution of their budgets, management and use of financial resources.

To solve this problem, it is necessary to ensure effective preliminary and current financial control over their activities, and to ensure the maximum 
transparency of local government activities and its control by the public, involving the citizens as much as possible in making managerial decisions and promoting the development of forms of direct democracy. Adhering to the rules of the European Charter of Local Self-Government, it is necessary to have a maximum balance between the principles of control over the activities of local self-government bodies and autonomy of local authorities. The state must control the legitimacy of community decisions, thus the state's influence must be strengthened. Moreover, it is better to provide overall control by a single body, not by many. After all, when there are many controlling bodies it is hard to speak about the integrity of local self-government.

The reform should give impetus to the full development of communities, the opportunity to improve life in every populated area and in the country as a whole and allow citizens to manage the place of residence by themselves.

\section{SUMMARY}

The article deals with the peculiarities of implementation of financial decentralization. It has been determined that financial decentralization is one of the fundamental conditions for the independence and viability of local authorities. Yet decentralization of decision-making processes increases the opportunities for local authorities to participate in the development of their own territory. It also promotes effective provision of public services through a close matching of expenditures of local authorities with top priority needs. The new challenges of financial decentralization of local public authorities are considered. Attention is drawn to the amalgamated territorial communities as part of the budget system of Ukraine. The peculiarities of forming budgets of the amalgamated territorial communities are analyzed. The article emphasizes on the necessity for proper control over the work of the authorities at different levels in the process of planning and execution of their budgets, management and the use of financial resources under the conditions of budget decentralization.

\section{REFERENCES}

1. Про місцеві державні адміністрації. Закон України від 9.04.1999 p. Відомості Верховної Ради Украӥни. 1999 № 20-21. st.190.

2. Про місцеве самоврядування. Закон України від 9.04 .1999 p. Відомості Верховної Ради Украӥни. 1997 № 24. ст. 170.

3. Конституція України від 28.06.1996 № 254к/96-ВР. Відомості Верховної Ради Украӥни. 1996. № 30. Ст. 141.

4. Приходько В.П., Сгорова О.О. Децентралізація в Україні : https://dspace.uzhnu.edu.ua/jspui/bitstream/lib/19803/1/Децентралізація_для $\% 20$ сайту.pdf 
5. https://decentralization.gov.ua/about

6. Про внесення змін до Бюджетного кодексу України та деяких інших законодавчих актів України. Закон України від 10.02.2015 № 176-VIII. Відомості Верховної Ради України. 2015. № 16. ст. 107.

7. Про внесення змін до Бюджетного кодексу України. Закон України від 07.12.2017 № 2233-VIII. Відомості Верховної Ради України. 2018. № 2. ст. 8.

8. Про добровільне об'єднання територіальних громад : Закон України від 5 лютого 2015 року № 157-VIII. Відомості Верховної Ради України. 2015. № 13. ст.91.

9. Концепція реформування місцевого самоврядування та територіальної організації влади в Україні : Розпорядження Кабінету Міністрів України від 1 квітня 2014 р. № 333-р.

10. Бюджетний кодекс від 8 липня 2010 року № 2456-VI. Вiдомості Верховної Ради Украӥни. 2010. № 50-51. t. 572

\section{Information about the author:}

Latkovskyi P. P.,

Candidate of Juridical Sciences, Senior Lecturer at the Department of Constitutional, Administrative and Finance Law, Chernivtsi Law Institute, National University "Odessa Law Academy" 7, Skovorody str., Chernivtsi, 58000, Ukraine 